\title{
John King Fairbank: A Memoir
}

John Fairbank was the master builder, the man who created the field of modern Chinese studies in the United States. He did this by making use of a dazzling rainbow of talents.

As a scholar, he pioneered the study of Qing documents and the interaction of China and the west, and became the first and, at the time of his death, the only historian of China to serve as President of the American Historical Association. As a Harvard mover and shaker he and Edwin O. Reischauer launched an undergraduate survey course on East Asian history and culture ("Rice Paddies 101"), which, in its latest incarnation, remains a popular staple of the curriculum over half a century later. He set up an East Asian regional studies MA programme which caters for an ever-expanding student body and established what is now the Fairbank Center for East Asian Research. As an inspiring graduate teacher he guided and cajoled future historians of China through the Ph.D. process and the transformation of theses into a flood of books, which were then published by or distributed through the Harvard University Press.

As a nationwide organizer, his myriad projects and fund-raising skills were major factors in the rapid expansion of modern Chinese studies after the Second World War. His energy and determination sparked initiatives, like the Committee on Chinese Thought and the Joint Committee on Contemporary China, which promote cohesion among university centres and a marriage of traditional sinology and modern social science.

As an indefatigable public educator, despite attacks from the right during the McCarthy era and from the left during the Vietnam War, he remained committed to his mission of imparting greater knowledge and understanding about China through speeches, broadcasts, articles, reviews and books. He completed the last of his great syntheses, China: A New History, only a couple of days before he died.

John Fairbank was born in South Dakota on 24 May 1907. He went to Harvard at the age of 20 for the last two years of his A.B., graduating summa cum laude and winning a Rhodes Scholarship to Balliol. A student of British history at that point, he was enticed into the study of China by the prospective publication of its diplomatic archives. By 1932 he was in Peiping, doing research for his dissertation which would eventually emerge as the pioneering monograph Trade and Diplomacy on the China Coast.

$\mathrm{He}$ joined the Harvard faculty in 1936, and began the task of making the professional study of modern China a normal part of a history department's curriculum. He spent the war years working for the United States government in Washington and China, an experience which led him to publish in 1948 his first and most widely-read book, The United States and China, a pithy digest of Chinese history and culture. Over the next four decades he wrote, co-wrote, edited or co-edited no fewer than three dozen volumes: monographic work on the Sino-western relationship during the 19th century; textbooks and 
analyses for scholars and students; bibliographic studies; and books designed to educate the general reader about China.

In the early 1950s, when I first met John Fairbank, Harvard's East Asian MA programme was the best and indeed almost the only one in the western world providing instruction in all facets of contemporary China. John was a constant and dominating presence; King John the Fair, one student dubbed him. His "Rice Paddies" lectures were models of clarity laced with a wry humour that teetered towards slapstick when he gave his famous rendering of coastal pidgin. He led a first-year seminar on sources-bibliographic control was his constant concern - and the MA thesis seminar in the second year: "You have to tell a story," he always insisted. Every Thursday he and his wife Wilma entertained our small coterie to tea, cucumber sandwiches and brownies at their house at 41 Dunster Street which helped to develop an esprit de corps under his leadership.

It was in an introductory seminar that John told us about his experiences during the McCarthy era, how he had been grilled for entertaining the political scientist Qian Duansheng who later returned to the PRC, and how Qian had suffered in China for consorting with the bourgeois American historian "Fei Zhengqing." John's conclusion from his experiences was not that a scholar should curb his pen or tongue, but rather than he ought to keep a record, in case memory played him false. Reischauer disagreed, arguing that the essence of intellectual inquiry was the scholar's right to change his mind. But John took his own advice. He would follow up phone calls and conversations with memoranda. Everything important was committed to writing in a manner that would have delighted a Qing mandarin.

When John asked me to work with him on the final volumes of The Cambridge History of China, I set aside the vow I took after retiring from this journal to give up editing; collaborating with my former teacher and continuing mentor on a major project was too much of a privilege to forego. John was a meticulous editor with a piercing eye for detail. There was no task too menial for him to worry about. With the help of devoted assistants, he charmed authors-in the six volumes of the Cambridge History for which he was responsible, he dealt with over 50 scholars based on four continents-processed manuscripts, ensured consistency, corrected grammar, demanded maps-John was an aficionado of railway maps-and pored over footnotes, bibliography and glossary index.

John's handling of his students was legendary. He had a few who were his special joy, but anyone he took on would receive the same conscientious supervision. He wanted people to flower in their own time and in their own way, but he hated them to waste their talents or opportunities. Once he flew to another campus where a dilatory former student, already an assistant professor, was still fussing over his Ph.D. thesis. He asked to look at the manuscript, took it back to Cambridge, and published it. 
While most of John's organizing genius was focused on Harvard and the United States - he once wrote "I love to create organizations"-he was very supportive of efforts to expand the field overseas. He followed the genesis and expansion of The China Quarterly with sympathetic attention and readily agreed to join the international advisory board when it was set up in the late 1960s. He was always particularly keen to work closely with Japanese scholars, for whose knowledge and understanding of China he had enormous respect; the successive efforts he made to master their language are amusingly described with characteristic self-deprecation in his autobiography, Chinabound.

John had an unerring eye for the ridiculous, in others and himself. His humour was a lifelong cascade of parodies, skits and one-liners; he wrote a hilarious circular dictated from his hospital bed describing his first heart attack in 1979. He also had a sense of occasion and a taste for the theatrical. For his last lecture before retiring, he dressed up in his Oxford D.Phil. robes, which he described as "the sort of colourful gewgaw the Hudson's Bay Company might have run up to dazzle the Northwest Indians." His characteristic comment on his last bow: "If you have to ride off into the sunset, you might as well look like a sunset."

RODERICK MACFARQUHAR 